\title{
Practical recommendations for fertility preservation in women by the FertiPROTEKT network. Part I: Indications for fertility preservation
}

\author{
A. N. Schüring ${ }^{1} \cdot$ T. Fehm ${ }^{2} \cdot$ K. Behringer ${ }^{3} \cdot$ M. Goeckenjan ${ }^{4} \cdot$ P. Wimberger ${ }^{4} \cdot$ M. Henes ${ }^{5} \cdot$ J. Henes $^{6} \cdot$ M. F. Fey $^{7}$. \\ M. von Wolff
}

Received: 30 October 2017 / Accepted: 10 November 2017 / Published online: 24 November 2017

(c) The Author(s) 2017. This article is an open access publication

\begin{abstract}
Purpose Most guidelines about fertility preservation are predominantly focused on scientific evidence, but are less practically orientated. Therefore, practically oriented recommendations are needed to support the clinician in daily practice.

Methods A selective literature search was performed based on the clinical and scientific experience of the authors, focussing on the most relevant diseases and gynaecological cancers. This article (Part I) provides information on topics that are essential for the fertility preservation indication, such as disease prognosis, disease therapy and its associated risks to fertility, recommending disease-specific fertility preservation measures. Part II specifically focusses on fertility preservation techniques.

Results In breast cancer patients, fertility preservation such as ovarian tissue and oocyte cryopreservation is especially recommended in low-stage cancer and in women $<35$ years of age. In Hodgkin's lymphoma, the indication is mainly based on the chemotherapy regime as some therapies have very low, others very high gonadotoxicity. In borderline ovarian tumours, preservation of fertility usually is achieved through fertility sparing surgery, ovarian stimulation may also be considered. In cervical cancer, endometrial cancer, rheumatic diseases and other malignancies such as Ewing sarcoma, colorectal carcinoma, non-Hodgkin lymphoma, leukaemia etc., several other factors must be considered to enable an individual, stage-dependent decision.

Conclusion The decision for or against fertility preservation depends on the prognosis, the risks to fertility and individual factors such as prospective family planning.
\end{abstract}

Keywords Fertility preservation · Breast cancer · Hodgkin's lymphoma $\cdot$ Borderline ovarian tumour $\cdot$ Cervical cancer · Rheumatic diseases

A. N. Schüring

Andreas.Schuering@ukmuenster.de

1 UKM Kinderwunschzentrum, Department of Gynaecology and Obstetrics, University Hospital of Münster, Albert-Schweitzer Campus 1, D-11, 48149 Münster, Germany

2 Department of Gynaecology and Obstetrics, University Hospital of Düsseldorf, Düsseldorf, Germany

3 Department I of Internal Medicine, University Hospital of Cologne, Cologne, Germany

4 Department of Gynaecology and Obstetrics, TU Dresden, Dresden, Germany
5 Department of Women's Health, University of Tübingen, Tübingen, Germany

6 Centre for Interdisciplinary Clinical Immunology, Rheumatology and Auto-inflammatory Diseases and Department of Internal Medicine II (Oncology, Hematology, Immunology, Rheumatology, Pulmology), University of Tübingen, Tübingen, Germany

7 Department of Medical Oncology, Inselspital and University of Berne, Berne, Switzerland

8 Division of Gynaecological Endocrinology and Reproductive Medicine, University Women's Hospital, Berne, Switzerland 


\section{Introduction}

Fertility preservation techniques have become an established part of oncology, rheumatology and many other areas. Several guidelines and recommendations have been published in Europe [1], the United States [2] and elsewhere. These guidelines mainly focus on scientific evidence, but are less practically orientated. The FertiPROTEKT network, a network and society of physicians and biologists specializing in fertility preservation in Germany, Austria and parts of Switzerland already published practical recommendations [3]. These recommendations have been updated, focusing on indications for fertility preservation, as well as on fertility preservation techniques in women who require therapies which can potentially lead to ovarian failure. As the topic has become too broad for one single paper, we have prepared two articles. This first article (Part I) provides disease-associated information, which is required for recommending fertility preservation procedures; a second article (Part II), also published in this journal, provides information about fertility preservation techniques. We aim to focus on topics that are essential in deciding for or against fertility preservation such as disease prognosis, disease-specific therapy and associated risks to fertility and to recommend disease-specific fertility preservation measures (Fig. 1).

\section{Breast cancer}

\section{Prognosis}

The prognosis of breast cancer is influenced by the tumour stage, intrinsic subtype and genetic classification. Stages II, III and IV display a mortality rate of 20, 44 and $66 \%$, respectively in women with breast cancer $<40$ years [4]. Triple negative breast cancer or a luminal B-type tumour are associated with an adverse prognosis [5]. While the overall 10 -year survival rate in all women with breast cancer is $86 \%$, the prognosis of younger patients $<35$ years is significantly lower, as aggressive subtypes and negative prognostic factors are more frequent in young women [6]. In young women with breast cancer diagnosed at age $<35$ years, it has been shown that the survival rate decreases by $5 \%$ for each year of lower age at diagnosis [7].

\section{Risks to fertility}

The chemotherapy-related risk of premature ovarian insufficiency (POI) is influenced by age, body mass index, the type and duration of therapy. After six cycles of $\mathrm{CMF}$, the risk of amenorrhoea is 33 and $81 \%$ in patients $<40$ and $\geq 40$ years of age, respectively [8]. Lower rates of persisting amenorrhoea were observed for newer therapy regimes such as AC-, ACT-, FAC- and FACT. In women $<30$ years, the risk of amenorrhoea was $10-20 \%$, but $13-68 \%$ for women $>30$ years [9] (Table 1).
Fig. 1 Decision tree for fertility preservation: criteria to decide for or against fertility preservation in women

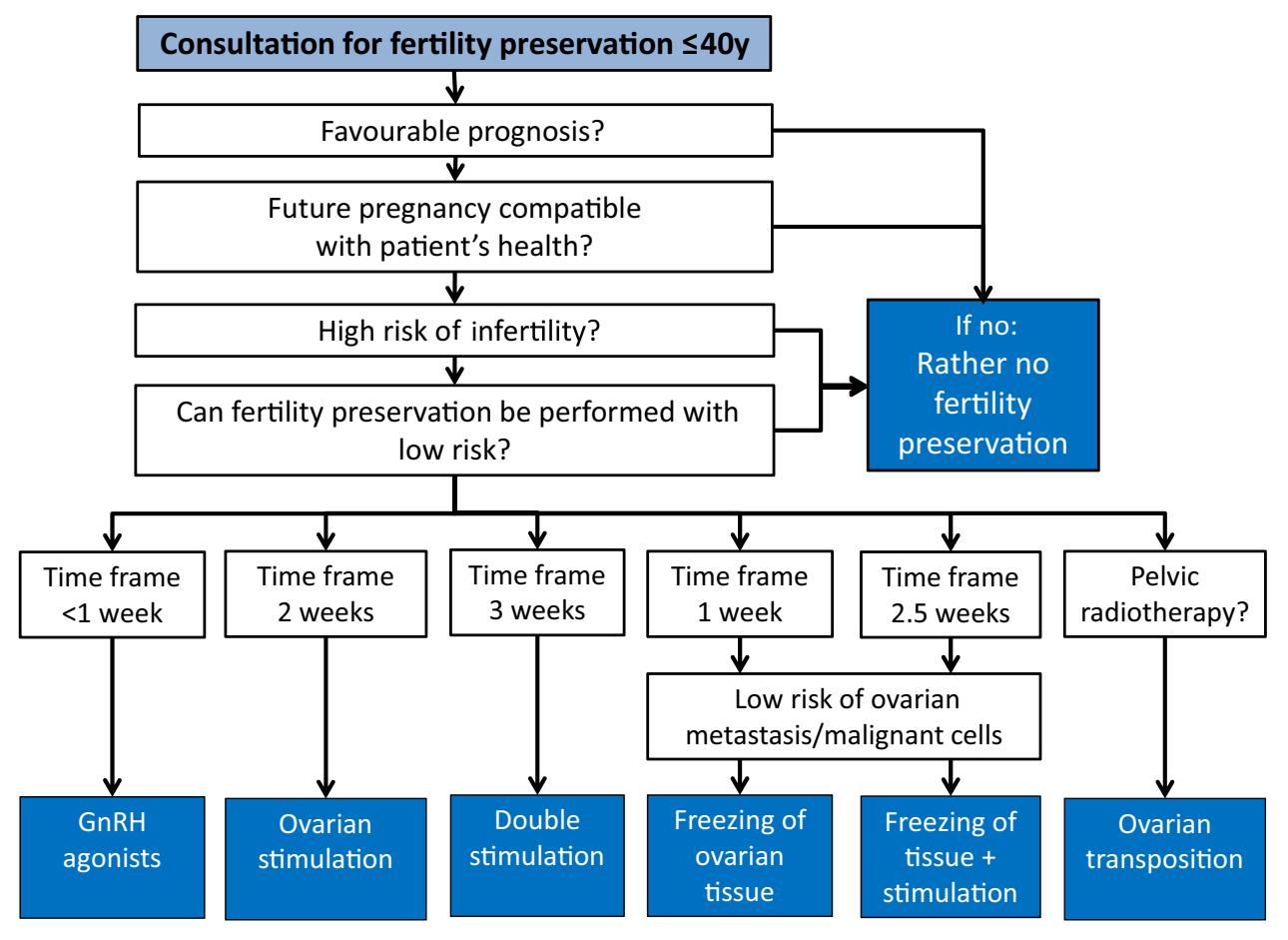


Table 1 Risk to fertility by gonadotoxic agents and regimes. Modified from $[1,113$, 114]

\begin{tabular}{|c|c|c|}
\hline Risk category & $\begin{array}{l}\text { Risk of permanent amen- } \\
\text { orrhoea }\end{array}$ & Agent/regime \\
\hline High risk & $80 \%$ & $\begin{array}{l}\text { HSC-TX with cyclophosphamide/TBI or cyclo- } \\
\text { phosphamide/busulfan } \\
\text { External beam radiotherapy including the ovaries } \\
\text { BEACOPP escalated ( } \geq 30 \text { years) } \\
6 \times \text { CMF, CEF, CAF, TAC ( } \geq 40 \text { years) } \\
\text { Procarbazine } \\
\text { Chlorambucil }\end{array}$ \\
\hline Intermediate risk & $40-60 \%$ & $\begin{array}{l}\text { BEACOPP escalated ( }<30 \text { years }) \\
6 \times \text { CMF, CEF, CAF, TAC (30-39 years) } \\
4 \times \text { AC }(\geq 40 \text { years }) \\
4 \times \text { AC or EC } \rightarrow \text { Taxanes }\end{array}$ \\
\hline & $\begin{array}{l}30 \% \\
12-54 \%\end{array}$ & $\begin{array}{l}\text { Monoclonal antibody: bevacizumab } \\
\text { MTX (cumulative risk increased in repeated } \\
\text { treatment of autoimmune disorders) }\end{array}$ \\
\hline Low risk & $<20 \%$ & $\begin{array}{l}\text { ABVD }(\geq 32 \text { years }) \\
4-6 \times \text { CHOP } \\
\text { CVP } \\
\text { AML therapy (anthracycline/cytarabine) } \\
\text { ALL therapy (multi-agent) } \\
6 \times \text { CMF, CEF, CAF, TAC ( } \leq 30 \text { years) } \\
4 \times \text { AC ( } \leq 40 \text { years) }\end{array}$ \\
\hline Very low or no risk & - & $\begin{array}{l}\text { ABVD }(<32 \text { years }) \\
\text { Methotrexate } \\
\text { Fluorouracil } \\
\text { Vincristine } \\
\text { Tamoxifen }\end{array}$ \\
\hline Unknown risk & - & $\begin{array}{l}\text { Monoclonal antibodies: trastuzumab, cetuximab } \\
\text { Tyrosine kinase inhibitors: erlotinib, imatinib }\end{array}$ \\
\hline
\end{tabular}

$H S C$-TX hematopoietic stem cell transplantation, TBI total body irradiation, CMF cyclophosphamide, methotrexate, fluorouracil, $C E F$ cyclophosphamide, epirubicin, fluorouracil, $C A F$ cyclophosphamide, doxorubicin, fluorouracil, TAC docetaxel, doxorubicin, cyclophosphamide, BEACOPP doxorubicin, bleomycin, vincristine, etoposide, cyclophosphamide, procarbazine, $A C$ doxorubicin, cyclophosphamide, $E C$ epirubicin, cyclophosphamide, $M T X$ methotrexate, $A B V D$ doxorubicin, bleomycin, vinblastine, dacarbazine, CHOP cyclophosphamide, doxorubicin, vincristine, prednisone, $C V P$ cyclophosphamide, vincristine, prednisone, $A M L$ acute myeloid leukaemia, $A L L$ acute lymphatic leukaemia
While adjuvant endocrine therapies are not gonadotoxic per se, the long duration of therapy poses a significant risk to fertility because of the natural decline in the ovarian reserve during therapy. Therefore, the increased age at the time when endocrine therapy is completed needs to be considered, if fertility preservation measures are discussed [10]. However, endocrine therapy may be interrupted for pregnancy after 2-3 years and can be continued afterwards, if patients are willing to accept a possibly increased risk for recurrence [11].

\section{Risk of ovarian metastasis}

The risk of ovarian metastasis is increased in higher tumour stages with peripheral metastases, in inflammatory and in lobular breast cancer. In tumours with negative lymph nodes, the risk of ovarian metastasis is low. Even in younger patients in higher disease stages and positive lymph nodes, the risk of ovarian metastasis at diagnosis seems to be low, but limited data are available [12-14]. In a study with 2648 young women with breast cancer of whom $2.4 \%$ had the diagnosis of ovarian metastasis, the median latency up to diagnosis of ovarian metastasis was 49 months [15]. In a small series using ovarian tissue from 13 women with advanced breast cancer, no metastases were observed after xenotransplantation into SCID mice [16].

The risk for women with BRCA1- and BRCA2-positive breast cancer of developing primary ovarian cancer is 15-65\% [17]. In BRCA1- and BRCA2-positive women with 
prophylactic salpingo-oophorectomy, the ovaries showed occult primary ovarian cancer in 6 and $2 \%$, respectively [18].

\section{Fertility preservation measures}

GnRH agonists have previously been suspected to impair the benefit of chemotherapy in hormone-sensitive breast cancer by causing ovarian suppression. However, as recent studies starting the endocrine ovarian suppression simultaneously with the (neo) adjuvant chemotherapy have questioned such a negative effect [19], this treatment option can be considered even in hormone-sensitive breast cancer.

Ovarian stimulation with oocyte cryopreservation is possible and appears to be safe [20]. If this is discussed with a patient shortly after diagnosis, the time interval before adjuvant chemotherapy is usually sufficient to allow single or double ovarian stimulation [21].

In hormone-sensitive breast cancer, controlled ovarian stimulation should be discussed individually with the patient and the oncologist. If stimulation is performed, estradiol levels should be reduced by aromatase inhibitors (or tamoxifene) and by GnRH agonist triggered ovulation without impairing clinical pregnancy rates and live birth rates in cryopreservation cycles [20,22-24] and oncological follow-ups [25].

Ovarian tissue cryopreservation appears to be safe, especially in low tumour stages. The stage-dependent risk for ovarian metastases should be discussed with the patient. Ovarian cryopreservation should not be performed in stage IV breast cancer. In patients with BRCA1- and BRCA2positive breast cancer, ovarian cryopreservation appears to be possible. After completion of family planning, transplants should be removed.

\section{Summarized recommendations}

- Fertility preservation is recommended in women with breast cancer with a good prognosis, with a moderate to high POI risk and/or age $>35$ years at the time of expected pregnancy.

- In hormone-insensitive breast cancer, GnRH agonists, ovarian stimulation for oocyte cryopreservation and ovarian tissue cryopreservation can be offered.

- In hormone-sensitive tumours, GnRH agonists and ovarian stimulation for oocyte cryopreservation should be discussed individually.

- If the time interval before chemotherapy is $<2$ weeks, e.g., in a neo-adjuvant situation, stimulation is not an option and ovarian tissue cryopreservation should be considered.

- A combination of fertility preserving measures, and freezing the ovarian tissue followed by ovarian stimulation with or without $\mathrm{GnRH}$ agonists can be offered.

\section{Hodgkin's lymphoma}

\section{Prognosis}

Prognosis in Hodgkin's lymphoma (HL) is age-related with high 15 -year survival rates of 94,91 and $87 \%$ in age groups of 18-29, 30-39 and 40-49 years, respectively [26, 27]. Prognosis also depends on disease stage, risk factors and therapeutic response.

\section{Risks to fertility}

Early stages are treated with ABVD chemotherapy, for intermediate stages, the German Hodgkin Study Group recommends $2 \times$ BEACOPP escalated plus $2 \times A B V D$ and for advanced stages, 4-6×BEACOPP escalated. In other countries, ABVD remains the standard also for advanced HL. BEACOPP escalated is associated with significantly higher gonadotoxicity than ABVD [28] and this effect is age-dependent. After $8 \times$ BEACOPP escalated, the rate of amenorrhoea was $51.4 \%$ in women aged $<30$ years and $95.0 \% \geq 30$ years [29]. Comparing the gonadotoxic effects of ABVD and BEACOPP escalated, post-treatment serum AMH was 2.2 vs. $0.1 \mu \mathrm{g} / \mathrm{l}$ at age $18-29$ years and 0.7 vs. $0.0 \mu \mathrm{g} / \mathrm{l}$ at age $30-45$ years [26]. While $90 \%$ of patients with early stages of $\mathrm{HL}$ who received ABVD $\pm 2 \times \mathrm{BEA}-$ COPP reported regular menstruation within 1 year of chemotherapy, amenorrhoea persisted in $25 \%$ of the 25 years old and in $50 \%$ of the 30 years old patients 4 years after 6-8×BEACOPP escalated [26] (Table 1). Radiotherapy in HL exerts an additional negative effect on fertility, when the ovaries are involved [30] (Table 2).

Table 2 Radiotoxicity and ovarian insufficiency. Modified from [96, 112]

\begin{tabular}{ll}
\hline Ovarian effects of radiotherapy & $\begin{array}{l}\text { Ovarian radio- } \\
\text { therapy dose } \\
(\mathrm{Gy})\end{array}$ \\
\hline No relevant effects & $\leq 0.6$ \\
No relevant effects $<40$ years & $\leq 1.5$ \\
Depletion of follicle pool by 50\% & 2.0 \\
Risk of ovarian insufficiency $60 \%$ (15-40 years) & $2.5-5.0$ \\
ESD 0 years (at birth) & 20.3 \\
ESD 10 years & 18.4 \\
ESD 20 years & 16.5 \\
ESD 30 years & 14.3 \\
ESD 40 years & 6.0 \\
\hline
\end{tabular}

The ESD is defined as the radiotherapy dose, which reduces the ovarian follicle pool to less than 1000 follicles in $97.5 \%$ of women [112] Gy gray, ESD effective sterilizing dose 


\section{Risk of ovarian metastasis}

Ovarian metastases were not detected in the four studies, including patients with advanced HL $[14,31,32]$. However, a case report observed HL within ovarian tissue in one patient in stage IIIb with hepatic involvement and pelvic lymphoma [33]. It can be concluded that the overall risk of ovarian metastasis is very low.

\section{Fertility preservation measures}

GnRH agonists and ovarian tissue cryopreservation are options for fertility preservation. Ovarian stimulation and oocyte cryopreservation is feasible, if the time interval before chemotherapy is sufficient to allow for stimulation. $\mathrm{HL}$ affecting the mediastinum can occasionally pose a risk for complications during intubation, making laparoscopy for ovarian cryopreservation impossible. Alternatively, if time is sufficient, ovarian stimulation can be offered, as transvaginal oocyte aspiration does not require intubation.

\section{Summarized recommendations}

- Fertility preservation is recommended in women $<40$ years with high POI risk (e.g., 6×BEACOPP escalated).

- In women with a low or moderate POI risk (e.g., $2 \times$ ABVD or $2 \times$ ABVD plus $2 \times$ BEACOPP escalated) fertility preservation can be considered.

- GnRH agonists, ovarian stimulation with oocyte cryopreservation and ovarian cryopreservation are adequate options for fertility preservation in HL.

- Laparoscopy for ovarian cryopreservation may not be possible in HL, if a mediastinal tumour impairs intubation.

- A combination of fertility preserving measures, $\mathrm{GnRH}$ agonists, and freezing of ovarian tissue followed by ovarian stimulation may be an option, if gonadotoxic risk is high, prognosis is good and time is sufficient.

\section{Borderline ovarian tumour and epithelial ovarian cancer}

\section{Prognosis}

Borderline ovarian tumours (BOT) are mainly diagnosed at an early stage with favorable prognosis, characterized by the absence of invasive peritoneal implants [34]. The 10 year survival rate is $97 \%$ for all FIGO stages, for Stage III and IV it is $90 \%$ [35].

Epithelial ovarian carcinomas are often detected at advanced stages with a 5-year survival rate of $42 \%$. In FIGO
I, the 5-year survival rate is $>90 \%$. The main prognostic factors are post-operative tumour mass and stage of disease, while others are age, constitution, grading, histologic type and guideline adherence during therapy.

\section{Risks to fertility}

Fertility in ovarian tumours is mainly compromised by the surgical procedure, but fertility sparing strategies exist. In epithelial ovarian cancer, chemotherapy can pose additional risks for fertility.

In BOT, guidelines require complete tumour removal, bilateral salpingo-oophorectomy and surgical staging, because the post-operative remaining tumour is the main prognostic factor. Chemotherapy is not indicated in BOT. In early epithelial ovarian carcinoma (FIGO IA, unilateral, G1), surgery involves complete tumour removal, bilateral salpingo-oophorectomy, hysterectomy, omentectomy, peritoneal biopsies and pelvic and para-aortic lymphadenectomy. Chemotherapy is indicated in FIGO > IA, G1.

\section{Fertility preservation measures}

In unilateral BOT, the contralateral adnexa can be preserved. If both ovaries are involved, organ-preserving cystectomy is often feasible [36, 37]. After family planning is complete, surgery should be completed according to guidelines. Fertility preserving surgery in BOT FIGO I is apparently not associated with a strong increase in oncological risk and fertility preservation is possible [38]. In retrospective observational studies, organ-preserving cystectomy resulted in an increased risk of recurrence [39]. In a large study, relapse rate after ovarian preservation was $12.5 \%$ in BOT FIGO I and $44 \%$ in BOT FIGO III, but only $13 \%$ in case of radical surgery [35]. Another study confirmed an increased relapse risk in the remaining ovarian tissue; however, no significant effect on survival rates could be observed, even when a malignant transformation occurred [40].

In early epithelial ovarian cancer (FIGO IA, unilateral, G1), fertility sparing surgery to preserve the uterus and one healthy ovary is also feasible, after adequate staging and informed consent about associated risks. In well-selected patients, fertility preserving surgery is not associated with a change in the recurrence-free interval or survival rate [41-43]. Exact staging, risk assessment and oncological monitoring until birth are required. Completion of surgery is recommended, after family planning is complete.

Ovarian stimulation for oocyte cryopreservation can be considered in BOT, because of the risk of recurrence and especially before salpingo-oophorectomy is performed [38]. Although it is not known if ovarian stimulation increases the risk of BOT relapse, it has been recommended to restrict the number of cycles [44]. 
In individual cases of early epithelial ovarian cancer (FIGO IA G1/G2) and after informed consent, in vitro fertilization (IVF) may be an option. However, in a meta-analysis of small studies on IVF after fertility sparing surgery in ovarian carcinoma, a potentially negative effect on the oncological outcome was observed [45].

Ovarian tissue cryopreservation is not recommended in BOT and in epithelial ovarian carcinoma, because of the risk of ovarian metastasis. However, experimental methods such as in vitro growth of ovarian tissue (IVG) and xenotransplantation of ovarian tissue into other species to generate follicles may become future strategies in malignant ovarian tumours.

\section{Summarized recommendations}

- In BOT and in early ovarian cancer FIGO IA G1 after complete staging, fertility sparing surgery to allow for pregnancy is feasible, followed by the completion of surgery after delivery.

- In ovarian cancer FIGO IA G2 after complete staging, fertility sparing surgery and achievement of pregnancy can be considered in individual cases, followed by the completion of surgery and chemotherapy.

- Ovarian stimulation with oocyte cryopreservation can be offered to all patients with BOT, when ovarian reserve is compromised by surgery. Ovarian tissue cryopreservation is not recommended in ovarian carcinoma, because of the high risk of relapse, but can be considered in individual cases if bilateral salpingo-oophorectomy is required.

\section{Cervical cancer}

\section{Prognosis}

The prognosis of cervical cancer is stage-dependent, with a high 5-year survival rate of 93\% for FIGO I. If lymph nodes are involved, the 5-year survival rate decreases to $20-60 \%$, depending on the localization of metastases. Other important prognostic factors are lymphangiosis, haemangiosis, grading, histology and infiltration of resection margins.

\section{Risks to fertility}

Fertility in treatment of cervical cancer can be compromised by the surgical procedure and by radiochemotherapy. Organpreserving cone-biopsy or large loop excision of the transformation zone (LLETZ) is performed for carcinoma in situ. While stages FIGO IA1, FIGO IA2 and selected cases of FIGO IB $1<2 \mathrm{~cm}$ can also be treated with fertility sparing procedures, cervical carcinoma FIGO IB $1 \geq 2 \mathrm{~cm}$ requires radical hysterectomy with bilateral salpingectomy, which is not compatible with fertility. In cervical adenocarcinoma, bilateral oophorectomy is recommended due to a potential risk of ovarian metastasis; however, the ovaries can possibly be preserved in stage FIGO < IB2.

In the case of combined radiochemotherapy, the detrimental effect on the ovaries is determined by the total and local radiotherapy dose in an age-dependent manner. The use of platinum as a radio-sensitizer in radiochemotherapy causes a potentiation of gonadotoxic effect. A radiotherapy dose of 14.3 Gy will cause complete ovarian insufficiency (sterilization) in $97.5 \%$ of women at age 30 [46] (Table 2). Craniolateral transposition of the ovaries should be considered.

Radiotherapy to the uterus in cervical cancer involves a total dose of 40-50 Gy and a boost of $9 \mathrm{~Gy}$ as a combination of percutaneous radiotherapy and brachytherapy. A uterine dose of more than $45 \mathrm{~Gy}$ is not compatible with future pregnancies [47] (Table 3).

\section{Risk of ovarian metastasis}

Ovarian metastases in early stages of cervical carcinoma without risk factors are infrequent, however, in adenocarcinoma in young women, the risk is significantly increased compared to squamous cell carcinoma ( 8.2 vs. $0.4 \%$, respectively) [48-50].

\section{Fertility preservation measures}

In cervical carcinoma in situ, cone-biopsy or LLETZ do not impair fertility, when the surgical technique aims at preserving cervical function during future pregnancy [51]. In microinvasive carcinoma FIGO IA1 with one risk factor and in FIGO IA2 without risk factors, cone-biopsy is eligible for fertility preservation, if a complete resection of the tumour
Table 3 Clinical effects of radiotherapy to the uterus. Modified from [47]

\footnotetext{
Radiotherapy during childhood has a more harmful effect on the uterus than during adulthood

Radiotherapy to an adult uterus during total body irradiation (TBI) with $12 \mathrm{~Gy}$ is associated with an increased risk of miscarriage, premature birth and low birth weight

After radiotherapy to the uterus with a dose $>25$ Gy during childhood, pregnancy is not advisable

After radiotherapy to the uterus with a dose $>45$ Gy during adulthood, pregnancy is not advisable
}

Gy gray, TBI total body irradiation 
is achieved (R0). Oncological results are comparable to hysterectomy $[52,53]$.

In FIGO IA2 plus one risk factor and in FIGO IA1 plus two risk factors, staging which confirms negative lymph node status is required to allow fertility sparing radical trachelectomy including cerclage $[54,55]$. Long-term outcome appears comparable to radical hysterectomy [56, 57]. In FIGO IB $1<2 \mathrm{~cm}$ and no risk factors, radical trachelectomy is also possible in selected cases.

For FIGO IB1 $\geq 2 \mathrm{~cm}$, radical hysterectomy with bilateral salpingectomy is indicated and preservation of the uterus is not possible. While preservation of the ovaries is possible in early squamous epithelial carcinoma, in adenocarcinoma, which carries a higher risk for ovarian metastases, this may be individually decided for FIGO < IB2 [58].

When cone-biopsy or trachelectomy are performed for fertility preservation in cervical cancer instead of radical hysterectomy, an increased risk of relapse must be discussed with the patient. In addition, an increased risk of miscarriage and premature birth must be considered [57, 59-62]. Downstaging by neo-adjuvant chemotherapy in advanced cervical cancer for uterus preservation has been described, but is currently considered experimental [63].

Craniolateral ovarian transposition can be performed before radiochemotherapy in selected cases. However, the surgical procedure itself can be associated with a reduction in the ovarian reserve [64].

Currently, it is under discussion whether GnRH agonists reduce the gonadotoxicity of chemotherapy. Ovarian tissue cryopreservation can be discussed, but the risk of ovarian metastases must be considered in adenocarcinoma. If legal in the respective country, surrogacy after oocyte cryopreservation could be an option in cases, where preservation of the uterus is not possible.

\section{Summarized recommendations}

- Fertility sparing surgery such as cone-biopsy or LLETZ is recommended in microinvasive cervical carcinoma FIGO IA1 with one risk factor and in FIGO IA2 without risk factors and if $\mathrm{R} 0$ resection is achieved.

- In FIGO IA1 with two risk factors and in FIGO IA2 with one risk factor, fertility preserving surgery in the form of radical trachelectomy according to D'Argent is possible, when staging confirms N0.

- In FIGO IB $1<2 \mathrm{~cm}$, radical trachelectomy with preservation of the ovaries is possible, the increased oncological risk must be individually assessed.

- In FIGO IB $\geq 2 \mathrm{~cm}$, uterus preservation is not possible.

- In cervical adenocarcinoma FIGO < IB2, the ovaries may be preserved in an individual decision.

- Craniolateral transposition of ovaries is an eligible procedure before radiotherapy.
- If the uterus cannot be preserved, ovarian stimulation and oocyte cryopreservation followed by surrogacy is an option, if legal in the respective country.

- Downstaging cervical cancer by neo-adjuvant chemotherapy to preserve the uterus is controversially discussed.

\section{Endometrial carcinoma and endometrial hyperplasia}

\section{Prognosis}

The prognosis in complex endometrial hyperplasia without and with atypia is excellent after progestin therapy and histological follow-up with hysteroscopy and curettage. In early endometrial carcinoma FIGO IA G1/G2, frequent in younger women $<45$ years, standard therapy by hysterectomy with salpingo-oophorectomy is associated with a very good prognosis and a 5-year survival rate of $94 \%$.

\section{Risks to fertility}

Therapy with progestin is not gonadotoxic, but delays realization of pregnancy. In endometrial carcinoma, the standard surgical procedure of hysterectomy with salpingo-oophorectomy is not compatible with fertility, but fertility sparing strategies exist for FIGO IA G1. Radiotherapy is indicated in higher stages of endometrial cancer not eligible for fertility preservation.

\section{Risk of ovarian metastasis}

The risk of ovarian metastasis in early endometrial carcinoma appears to be low [65]. Synchronous ovarian cancer may be present, especially in women with Lynch syndrome [66].

\section{Fertility preservation measures}

In complex endometrial hyperplasia without atypia, cyclic progestin therapy is indicated (e.g., 10-20 mg MPA/day), followed by control hysteroscopy and curettage after 3-6 months before pregnancy is achieved. Alternatively, pregnancy is realized first, followed by progestin therapy.

In complex endometrial hyperplasia with atypia, progestin therapy with $100 \mathrm{mg}$ MPA/day with hysteroscopic and histological follow-up after 3 and 9 months is indicated, followed by the realization of pregnancy.

In well-differentiated type I endometrial carcinoma without infiltration of the myometrium FIGO IA G1, hysteroscopy and curettage for tumour removal is possible, followed by progestin therapy for 6-12 months (e.g., $250 \mathrm{mg}$ MPA/day or a progestin containing intrauterine device). Hysteroscopic follow-up and 
curettage are required every 3 months. After cessation of progestin, the realization of a pregnancy is possible in a limited time interval. After pregnancy, stage-adjusted completion of surgery by hysterectomy and salpingo-oophorectomy is indicated, because of a high recurrence risk [67-70].

The preservation of the uterus and adnexa in endometrial carcinoma is associated with an increased oncological risk, because of inadequate staging. A risk of ovarian metastasis or synchronous primary ovarian carcinoma must be considered, probably being $<1 \%$ in early endometrial carcinoma in young women $[71,72]$. However, the preservation of ovaries in low-grade endometrial carcinoma does not appear to impair recurrence-free intervals [73, 74].

IVF has been proposed to reduce the time to pregnancy before a completion of surgery [75, 76]. Hormonal stimulation for oocyte cryopreservation appears possible, if stimulated estradiol levels are reduced with an aromatase-inhibitor or an anti-oestrogen and ovulation is induced by a GnRH agonist. Ovarian tissue cryopreservation appears possible in early endometrial carcinoma, because of a low risk of metastases.

\section{Summarized recommendations}

- In endometrial hyperplasia without atypia, cyclic progestin therapy is indicated (e.g., 10-20 mg MPA/day), with follow-up hysteroscopy and curettage after 3-6 months before a pregnancy is achieved.

- In endometrial hyperplasia with atypia, MPA $100 \mathrm{mg} / \mathrm{day}$ or a progestin-releasing IUD is indicated, with follow-up hysteroscopy and curettage after 3 and after 9 months, before pregnancy can be achieved.

- In individual cases of progesterone receptor-positive endometrial carcinoma FIGO IA G1, tumour removal by hysteroscopy and curettage is possible for fertility preservation, followed by progestin therapy with $250 \mathrm{mg}$ MPA for 6-12 months with follow-up in three-monthly intervals. The realization of a pregnancy is then possible within a limited time frame. After pregnancy or in case of relapse, completion of surgery is indicated.

- Fertility preservation is not possible in progesterone receptor-negative endometrial carcinoma FIGO IA G1, or in tumours with higher stages or higher grading. In these cases, hysterectomy with bilateral salpingo-oophorectomy is indicated.

\section{Rheumatic and autoimmune disorders}

\section{Prognosis}

Rheumatic and autoimmune disorders cannot be cured; however, life expectancy can be significantly improved when treated adequately.

\section{Risks to fertility}

Ovarian reserve is impaired by cyclophosphamide (CYC), which is used for immune suppression over a limited time interval in highly active disease stages (orally or as an intravenous pulse therapy). While a single treatment cycle appears to have limited gonadotoxicity, repeated cycles are needed to control the disease and may be necessary again throughout the patient's life, increasing the cumulative CYC-dose. CYC significantly increases the risk of premature ovarian insufficiency (POI) in patients with autoimmune diseases, ranging from 12 to $54 \%$ in the literature, depending on age and cumulative CYC-dose [77, 78]. In addition, ovarian reserve can be reduced by the autoimmune disease per se [79-81]. Consultation about fertility preservation in autoimmune diseases, therefore, is recommended before CYC-therapy [82].

\section{Fertility preservation measures}

The following recommendations are mainly based on evidence available for systemic lupus erythematosus (SLE), because limited data exist for other autoimmune diseases.

Female sex steroids are assumed to contribute to the pathogenesis of SLE, which could account for the observed exacerbation of the disease during ovarian stimulation for fertility preservation. In contrast, positive effects on the disorder associated with GnRH agonists suppressing ovarian function have also been observed [83]. In this context, the exacerbation risk of rheumatic disorders during $\mathrm{GnRH}$ agonist therapy is low. While their efficacy in fertility preservation for other disorders appears to vary [84], a protective effect of GnRH agonists specifically in autoimmune disorders has been observed [85-88]. A recent consensus recommends GnRH agonists for young women with SLE who are receiving alkylating agents [82].

Ovarian stimulation is associated with a significant exacerbation risk in SLE, which is probably little less present in primary antiphospholipid syndrome (APS) [89]. The risk of venous thromboembolism (VTE) is increased in autoimmune disorders, being the highest in active stages of APS and SLE. When lupus anticoagulant is present, VTE risk is increased sixfold [90]. Data on VTE risk associated with ovarian hormonal stimulation in autoimmune disease is limited. No VTE was observed in a study on 68 stimulated cycles of 19 patients with SLE and APS who received antithrombotic prophylaxis [89]. In active stages of autoimmune diseases, hormonal stimulation for fertility preservation may be considered in individual cases; sufficient VTE-prophylaxis is required [82]. However, especially in connective tissue diseases, hormonal stimulation may not be indicated because of the exacerbation risk. 
Cryopreservation of ovarian tissue is an eligible option in autoimmune disorders. A disease-related reduction of the ovarian reserve should be evaluated in advance.

\section{Summarized recommendations}

- Fertility preservation should be recommended in young women with autoimmune disorders, when CYC-therapy is indicated.

- GnRH agonists are an eligible option for fertility preservation in autoimmune diseases.

- Ovarian stimulation and cryopreservation of oocytes can be applied in individual cases, if risk of exacerbation is low and sufficient time is available. Effective thrombosis prophylaxis is required.

- Cryopreservation of ovarian tissue is an option, if ovarian reserve is sufficient.

\section{Other malignant diseases}

\section{Ewing sarcoma}

\section{Prognosis}

The prognosis in Ewing sarcoma is categorized into risk classes according to the 5-year survival rate (in brackets):

- Standard risk (70-75\%): localized tumour, good response to neo-adjuvant chemotherapy.

- High risk (50\%): localized tumour, volume $>200 \mathrm{ml}$, reduced response to neo-adjuvant chemotherapy, pulmonary metastases.

- Very high risk (20-40\%): all other.

\section{Risks to fertility}

Chemotherapy-related premature ovarian insufficiency (POI) in Ewing sarcoma occurs in $\geq 50 \%$ of patients. A significantly higher risk of infertility is expected in case of pelvic radiotherapy or haematopoietic stem cell transplantation [91].

\section{Risk of ovarian metastasis}

Ovarian metastases were observed in single cases $[14,50$, 92-94], but were not confirmed in all the studies [95].

\section{Fertility preservation measures}

GnRH agonists and, if the time interval before oncological therapy is sufficient, ovarian stimulation with oocyte cryopreservation can be considered. Ovarian tissue cryopreservation is possible. A risk of ovarian metastasis must be discussed. Ovarian transposition is possible, if pelvic radiotherapy is performed [96].

\section{Osteosarcoma}

\section{Prognosis}

The prognosis of osteosarcoma depends on tumour stage with a 5-year survival rate of $20-80 \%$.

\section{Risks to fertility}

The risk of premature ovarian insufficiency (POI) was reported to affect 6 of 90 women, after chemotherapy (6.6\%) [97].

\section{Risk of ovarian metastasis}

Ovarian metastases are possible, but were not detected in small studies [14, 92].

\section{Fertility preservation measures}

Comparable to Ewing sarcoma, GnRH agonists and, if the time interval before oncological therapy is sufficient, ovarian stimulation with oocyte cryopreservation can be considered. Ovarian tissue cryopreservation is possible, if the risk of ovarian metastasis is discussed. Ovarian transposition is possible, if pelvic radiotherapy is performed [96].

\section{Colorectal carcinoma}

\section{Prognosis}

The 5-year survival rate in tumour stages pT1-3 after R0-resection in colorectal carcinoma is $90,80,60 \%$ and in rectal carcinoma $90,70,40 \%$, respectively.

\section{Risks to fertility}

The chemotherapy-induced risk of premature ovarian insufficiency (POI) is low to moderate, but high if radiochemotherapy is performed [98-100]. A radiotherapy dose of 45-50 Gy causes POI in $>90 \%$ of patients with rectal carcinoma.

\section{Risk of ovarian metastasis}

The risk of ovarian metastasis seems to be low in tumour stages pT1-3 [14, 50]. 


\section{Fertility preservation measures}

If chemotherapy is indicated, GnRH agonists, ovarian stimulation for cryopreservation of oocytes, and ovarian tissue cryopreservation are possible options for fertility preservation. Ovarian transposition should be considered, if radiotherapy is performed. Gestational surrogacy after cryopreservation of oocytes or ovarian tissue may be an option, if legal in the respective country.

\section{Non-Hodgkin lymphoma (NHL)}

\section{Prognosis}

The prognosis in NHL varies greatly and depends on the respective entity of the heterogeneous disease.

\section{Risks to fertility}

The risk for the ovarian reserve in NHL is determined by chemotherapy and radiotherapy. It can be high with a POI rate of 40-60\% in women of age $>35$ years for CHOP and VA-CHOP-B [101, 102] (Table 1).

\section{Risk of ovarian metastasis}

The risk of ovarian metastasis is high in high-grade NHL and Burkitt's lymphoma [103]. Other types of NHL exhibit a lower, but still clinically relevant risk [14, 32].

\section{Fertility preservation measures}

GnRH agonists are an option for fertility preservation. Ovarian transposition can be considered, if pelvic radiotherapy is performed. Ovarian stimulation for cryopreservation of oocytes, and ovarian tissue cryopreservation are not recommended, because of the risk of ovarian metastasis.

\section{Acute lymphoblastic leukaemia (ALL)}

\section{Prognosis}

The 5-year survival rate in children is $80-90 \%$, but much lower in adults with a range of $20-45 \%$ depending on the age group [104, 105].

\section{Risks to fertility}

A moderate to high POI risk is conveyed by chemotherapy in ALL; the risk is very high in autologous or allogenic stem cell transplantation (Table 1).

\section{Risk of ovarian metastasis}

ALL conveys a high risk for ovarian involvement with leukaemic cells [50, 92, 106].

\section{Fertility preservation measures}

GnRH agonists are an option for fertility preservation. GnRH agonist-induced amenorrhoea prevents menstrual bleeding during oncological therapy. Ovarian stimulation with cryopreservation of oocytes is often not possible due to the limited time available. Ovarian cryopreservation is experimental because of the high risk of ovarian malignant cells. In vitro growth (IVG) or xenotransplantation may become future strategies.

\section{Acute myeloid leukaemia (AML)}

\section{Prognosis}

The 5-year overall survival rate is $24-80 \%$ in adults depending on the risk group, and $60 \%$ in children $<15$ years [104].

\section{Risks to fertility}

The risk of POI conveyed by chemotherapy is moderate to high; in autologous or allogenic stem cell transplantation, it is very high [107] (Table 1).

\section{Risk of ovarian metastasis}

The risk of malignant cells in the ovaries is high [50, 92].

\section{Fertility preservation measures}

Comparable to ALL, GnRH agonists are an option for fertility preservation in AML and GnRH agonist-induced amenorrhoea prevents menstrual bleeding during oncological therapy. Ovarian stimulation with cryopreservation of oocytes is often not possible due to the limited time available. Ovarian tissue cryopreservation is experimental because 
of the high risk of ovarian malignant cells. In vitro growth (IVG) or xenotransplantation may become future strategies.

\section{Effects of radiotherapy}

\section{Gonadal function}

The effects of radiotherapy on the ovaries are difficult to estimate because of individual variation. Table 2 gives an overview of some effects and the respective radiotherapy dose.

\section{Uterine function}

After total body irradiation (TBI) with a median of $10 \mathrm{~Gy}$, a birth weight of $<2500 \mathrm{~g}$ was found in approximately $30 \%$ of children, compared to $10 \%$ of controls without radiotherapy [108]. After direct pelvic radiotherapy, only scarce data are available [109-111]. In a systematic analysis, it was observed that radiotherapy during childhood appears to have stronger detrimental effects on the uterus than in adulthood. Radiotherapy to the uterus in TBI of 12 Gy was associated with a higher risk of miscarriage, premature birth and low birth weight. After a radiotherapy dose of $>25$ Gy during childhood, a pregnancy is not advisable; in adulthood, the respective upper limit is 45 Gy [47]. Table 3 shows the effects of different radiotherapy doses on the uterus.

Acknowledgements We thank Dr. Elizabeth Krämer for the linguistic revision and correction of the manuscript.

Author contributions AN Schüring: Project development, literature search, manuscript writing. T Fehm: Literature search, manuscript writing. K. Behringer: Literature search, manuscript writing. M. Goeckenjan: Literature search, manuscript writing. P. Wimberger: Literature search, manuscript writing. M. Henes: Literature search, manuscript writing. J. Henes: Literature search, manuscript writing. M. F. Fey: Literature search, manuscript writing. M. von Wolff: Project development, literature search, manuscript writing.

\section{Compliance with ethical standards}

Conflict of interest The authors declare that they have no conflicts of interest.

Open Access This article is distributed under the terms of the Creative Commons Attribution 4.0 International License (http://creativecommons.org/licenses/by/4.0/), which permits unrestricted use, distribution, and reproduction in any medium, provided you give appropriate credit to the original author(s) and the source, provide a link to the Creative Commons license, and indicate if changes were made.

\section{References}

1. Lambertini M, Del Mastro L, Pescio MC, Andersen CY, Azim HA Jr, Peccatori FA, Costa M, Revelli A, Salvagno F, Gennari A,
Ubaldi FM, La Sala GB, De Stefano C, Wallace WH, Partridge $\mathrm{AH}$, Anserini P (2016) Cancer and fertility preservation: international recommendations from an expert meeting. BMC Med 14:1. https://doi.org/10.1186/s12916-015-0545-7

2. Loren AW, Mangu PB, Beck LN, Brennan L, Magdalinski AJ, Partridge AH, Quinn G, Wallace WH, Oktay K, American Society of Clinical Oncology (2013) Fertility preservation for patients with cancer: American Society of Clinical Oncology clinical practice guideline update. J Clin Oncol 31:2500-2510. https:// doi.org/10.1200/JCO.2013.49.2678

3. von Wolff M, Montag M, Dittrich R, Denschlag D, Nawroth F, Lawrenz B (2011) Fertility preservation in women-a practical guide to preservation techniques and therapeutic strategies in breast cancer, Hodgkin's lymphoma and borderline ovarian tumours by the fertility preservation network FertiPROTEKT. Arch Gynecol Obstet 284:427-435. https://doi.org/10.1007/ s00404-011-1874-1

4. Gnerlich JL, Deshpande AD, Jeffe DB, Sweet A, White N, Margenthaler JA (2009) Elevated breast cancer mortality in women younger than age 40 years compared with older women is attributed to poorer survival in early-stage disease. J Am Coll Surg 208:341-347

5. Cancello G, Maisonneuve P, Rotmensz N, Viale G, Mastropasqua MG, Pruneri G, Veronesi P, Torrisi R, Montagna E, Luini A, Intra M, Gentilini O, Ghisini R, Goldhirsch A, Colleoni M (2010) Prognosis and adjuvant treatment effects in selected breast cancer subtypes of very young women $(<35$ years) with operable breast cancer. Ann Oncol 21:1974-1981

6. Anders CK, Hsu DS, Broadwater G, Acharya CR, Foekens JA, Zhang Y, Wang Y, Marcom PK, Marks JR, Febbo PG, Nevins JR, Potti A, Blackwell KL (2008) Young age at diagnosis correlates with worse prognosis and defines a subset of breast cancers with shared patterns of gene expression. J Clin Oncol 26:3324-3330. https://doi.org/10.1200/JCO.2007.14.2471

7. Han W, Kang SY, Korean Breast Cancer Society (2010) Relationship between age at diagnosis and outcome of premenopausal breast cancer: age less than 35 years is a reasonable cut-off for defining young age-onset breast cancer. Clin Breast Cancer Res Treat 119:193-200

8. Goldhirsch A, Gelber RD, Castiglione M (1990) The magnitude of endocrine effects of adjuvant chemotherapy for premeno- pausal breast cancer patients: the International Breast Cancer Study Group. Ann Oncol 1:183-188

9. Sukumvanich P, Case LD, Van Zee K, Singletary SE, Paskett ED, Petrek JA, Naftalis E, Naughton MJ (2010) Incidence and time course of bleeding after longterm amenorrhea after breast cancer treatment: a prospective study. Cancer 116:3102-3111

10. Llarena NC, Estevez SL, Tucker SL, Jeruss JS (2015) Impact of fertility concerns on tamoxifen initiation and persistence. J Natl Cancer Inst. https://doi.org/10.1093/jnci/djv202

11. Raphael J, Trudeau ME, Chan K (2015) Outcome of patients with pregnancy during or after breast cancer: a review of the recent literature. Curr Oncol 22:S8-S18. https://doi.org/10.3747/ co. 22.2338

12. Sanchez-Serrano M, Novella-Maestre E, Rosello-Sastre E, Camarasa N, Teruel J, Pellicer A (2009) Malignant cells are not found in ovarian cortex from breast cancer patients undergoing ovarian cortex cryopreservation. Hum Reprod 24:2238-2243

13. Rosendahl M, Timmermans Wielenga V, Nedergaard L, Kristensen SG, Ernst E, Rasmussen PE, Anderson M, Schmidt KT, Andersen CY (2011) Cryopreservation of ovarian tissue for fertility preservation: no evidence of malignant cell contamination in ovarian tissue from patients with breast cancer. Fertil Steril 95:2158-2161

14. Hoekman EJ, Smit VT, Fleming TP, Louwe LA, Fleuren GJ, Hilders CG (2015) Searching for metastases in ovarian tissue 
before autotransplantation: a tailor-made approach. Fertil Steril 103:469-477

15. Peters IT, van Zwet EW, Smit VT, Liefers GJ, Kuppen PJ, Hilders CG, Trimbos JB (2017) Prevalence and risk factors of ovarian metastases in breast cancer patients $<41$ years of age in the Netherlands: a nationwide retrospective cohort study. PLoS One 12:e0168277. https://doi.org/10.1371/journal.pone.0168277 (eCollection 2017)

16. Luyckx V, Durant JF, Camboni A, Gilliaux S, Amorim CA, Van Langendonckt A, Irenge LM, Gala JL, Donnez J, Dolmans MM (2013) Is transplantation of cryopreserved ovarian tissue from patients with advanced-stage breast cancer safe? A pilot study. J Assist Reprod Genet 30:1289-1299. https://doi.org/10.1007/ s10815-013-0065-3

17. Bougie O, Weberpals JI (2011) Clinical considerations of BRCA1 - and BRCA2- mutation carriers: a review. Int J Surg Oncol 2011:374012. https://doi.org/10.1155/2011/374012

18. Finch A, Shaw P, Rosen B, Murphy J, Narod SA, Colgan TJ (2006) Clinical and pathologic findings of prophylactic salpingooophorectomies in 159 BRCA1 and BRCA2 carriers. Gyneco Oncol 100:58-64

19. Bernhard J, Luo W, Ribi K, Colleoni M, Burstein HJ, Tondini C, Pinotti G, Spazzapan S, Ruhstaller T, Puglisi F, Pavesi L, Parmar V, Regan MM, Pagani O, Fleming GF, Francis PA, Price KN, Coates AS, Gelber RD, Goldhirsch A, Walley BA (2015) Patientreported outcomes with adjuvant exemestane versus tamoxifen in premenopausal women with early breast cancer undergoing ovarian suppression (TEXT and SOFT): a combined analysis of two phase-III randomized trials. Lancet Oncol 16:848-858

20. Rodgers RJ, Reid GD, Koch J, Deans R, Ledger WL, Friedlander M, Gilchrist RB, Walters KA, Abbott JA (2017) The safety and efficacy of controlled ovarian hyperstimulation for fertility preservation in women with early breast cancer: a systematic review. Hum Reprod 32:1033-1045. https://doi.org/10.1093/humrep/ $\operatorname{dex} 027$

21. Baynosa J, Westphal LM, Madrigrano A, Wapnir I (2009) Timing of breast cancer treatments with oocyte retrieval and embryo cryopreservation. J Am Coll Surg 209:603-607. https://doi. org/10.1016/j.jamcollsurg.2009.08.006

22. Meirow D, Raanani H, Maman E, Paluch-Shimon S, Shapira M, Cohen Y, Kuchuk I, Hourvitz A, Levron J, Mozer-Mendel M, Brengauz M, Biderman H, Manela D, Catane R, Dor J, Orvieto R, Kaufman B (2014) Tamoxifen co-administration during controlled ovarian hyperstimulation for in vitro fertilization in breast cancer patients increases the safety of fertility-preservation treatment strategies. Fertil Steril 102(488-495):e3. https://doi. org/10.1016/j.fertnstert.2014.05.017

23. Revelli A, Porcu E, Levi Setti PE, Delle Piane L, Merlo DF, Anserini P (2013) Is letrozole needed for controlled ovarian stimulation in patients with estrogen receptor-positive breast cancer? Gynecol Endocrinol 29:993-996. https://doi.org/10.3109/09513 590.2013.819083

24. Oktay K, Turan V, Bedoschi G, Pacheco FS, Moy F (2015) Fertility preservation success subsequent to concurrent aromatase inhibitor treatment and ovarian stimulation in women with breast cancer. J Clin Oncol 33:2424-2429. https://doi.org/10.1200/ JCO.2014.59.3723

25. Kim J, Turan V, Oktay K (2016) Long-term safety of letrozole and gonadotropin stimulation for fertility preservation in women with breast cancer. J Clin Endocrinol Metab 101:1364-1371. https://doi.org/10.1210/jc.2015-3878

26. Behringer K, Mueller H, Goergen H, Thielen I, Eibl AD, Stumpf V, Wessels C, Wiehlputz M, Rosenbrock J, Halbsguth T, Reiners KS, Schober T, Renno JH, von Wolff M, van der Ven K, Kuehr M, Fuchs M, Diehl V, Engert A, Borchmann P (2013) Gonadal function and fertility in survivors after Hodgkin lymphoma treatment within the German Hodgkin study group HD13 to HD15 Trials. J Clin Oncol 31:231-239

27. Glimelius I, Ekberg S, Jerkeman M, Chang ET, Bjorkholm M, Andersson TM, Smedby KE, Eloranta S (2015) Long-term survival in young and middle-aged Hodgkin lymphoma patients in Sweden 1992-2009-trends in cure proportions by clinical characteristics. Am J Hematol 90:1128-1134

28. Kulkarni SS, Sastry PS, Saikia TK, Parikh PM, Gopal R, Advani SH (1997) Gonadal function following ABVD therapy for Hodgkin's disease. Am J Clin Oncol 20:354-357

29. Behringer K, Breuer K, Reineke T, May M, Nogova L, Klimm B, Schmitz T, Wildt L, Diehl V, Engert A, German Hodgkin's Lymphoma Study Group (2005) Secondary amenorrhea after Hodgkin's lymphoma is influenced by age at treatment, stage of disease, chemotherapy regimen, and the use of oral contraceptives during therapy: a report from the German Hodgkin's Lymphoma Study Group. J Clin Oncol 23:7555-7564

30. De Bruin ML, Huisbrink J, Hauptmann M, Kuenen MA, Ouwens GM, van't Veer MB, Aleman BM, van Leeuwen FE (2008) Treatment-related risk factors for premature menopause following Hodgkin lymphoma. Blood 111:101-108

31. Seshadri T, Gook D, Lade S, Spencer A, Grigg A, Tiedemann K, McKendrick J, Mitchell P, Stern C, Seymour JF (2006) Lack of evidence of disease contamination in ovarian tissue harvested for cryopreservation from patients with Hodgkin lymphoma and analysis of factors predictive of oocyte yield. Br J Cancer 94:1007-1010

32. Meirow D, Hardan I, Dor J, Fridman E, Elizur S, Ra' anani H, Slyusarevsky E, Amariglio N, Schiff E, Rechavi G, Nagler A, Ben Yehuda D (2008) Searching for evidence of disease and malignant cell contamination in ovarian tissue stored from hematologic cancer patients. Hum Reprod 23:1007-1013

33. Bittinger SE, Nazaretian SP, Gook DA, Parmar C, Harrup RA, Stern CJ (2011) Detection of Hodgkin lymphoma within ovarian tissue. Fertil Steril 95(803):e3-e6. https://doi.org/10.1016/j. fertnstert.2010.07.1068

34. Seong SJ, Kim DH, Kim MK, Song T (2015) Controversies in borderline ovarian tumors. J Gynecol Oncol 26:343-349

35. du Bois A, Ewald-Riegler N, de Gregorio N, Reuss A, Mahner S, Fotopoulou C, Kommoss F, Schmalfeldt B, Hilpert F, Fehm T, Burges A, Meier W, Hillemanns P, Hanker L, Hasenburg A, Strauss HG, Hellriegel M, Wimberger P, Keyver-Paik MD, Baumann K, Canzler U, Wollschlaeger K, Forner D, Pfisterer J, Schröder W, Münstedt K, Richter B, Kommoss S, Hauptmann S, Arbeitsgemeinschaft Gynäkologische Onkologie (AGO) Study Group (2013) Borderline tumours of the ovary: a cohort study of the Arbeitsgmeinschaft Gynäkologische Onkologie (AGO) Study Group. Eur J Cancer 49:1905-1914. https://doi.org/10.1016/j. ejca.2013.01.035

36. Uzan C, Kane A, Rey A, Gouy S, Duvillard P, Morice P (2010) Outcomes after conservative treatment of advanced-stage serous borderline tumors of the ovary. Ann Oncol 21:55-60

37. Fauvet R, Poncelet C, Boccara J, Descamps P, Fondrinier E, Darai E (2005) Fertility after conservative treatment for borderline ovarian tumors: a French multicenter study. Fertil Steril 83:284-290

38. Mangili G, Somigliana E, Giorgione V, Martinelli F, Filippi F, Petrella MC, Candiani M, Peccatori F (2016) Fertility preservation in women with borderline ovarian tumours. Cancer Treat Rev 49:13-24. https://doi.org/10.1016/j.ctrv.2016.06.010

39. Suh-Burgmann E (2006) Long-term outcomes following conservative surgery for borderline tumor of the ovary: a large population-based study. Gynecol Oncol 103:841-847

40. Trillsch F, Mahner S, Woelber L, Vettorazzi E, Reuss A, Ewald-Riegler N, de Gregorio N, Fotopoulou C, Schmalfeldt B, Burges A, Hilpert F, Fehm T, Meier W, Hillemanns P, 
Hanker L, Hasenburg A, Strauss HG, Hellriegel M, Wimberger P, Baumann K, Keyver-Paik MD, Canzler U, Wollschlaeger K, Forner D, Pfisterer J, Schroeder W, Muenstedt K, Richter B, Kommoss F, Hauptmann S, du Bois A (2014) Age-dependent differences in borderline ovarian tumours (BOT) regarding clinical characteristics and outcome: results from a sub-analysis of the Arbeitsgemeinschaft Gynaekologische Onkologie (AGO) ROBOT study. Ann Oncol 25:1320-1327

41. Wright JD, Shah M, Mathew L, Burke WM, Culhane J, Goldman N, Schiff PB, Herzog TJ (2009) Fertility preservation in young women with epithelial ovarian cancer. Cancer $115: 4118-4126$

42. Bentivegna E, Fruscio R, Roussin S, Ceppi L, Satoh T, Kajiyama H, Uzan C, Colombo N, Gouy S, Morice P (2015) Long-term follow-up of patients with an isolated ovarian recurrence after conservative treatment of epithelial ovarian cancer: review of the results of an international multicenter study comprising 545 patients. Fertil Steril 104:1319-1324. https://doi.org/10.1016/j. fertnstert.2015.06.008

43. Fruscio R, Ceppi L, Corso S, Galli F, Dell'Anna T, Dell'Orto F, Giuliani D, Garbi A, Chiari S, Mangioni C, Milani R, Floriani I, Colombo N, Bonazzi CM (2016) Long-term results of fertilitysparing treatment compared with standard radical surgery for early-stage epithelial ovarian cancer. Br J Cancer 115:641-648. https://doi.org/10.1038/bjc.2016.254

44. Denschlag D, von Wolff M, Amant F, Kesic V, Reed N, Schneider A, Rodolakis A (2010) Clinical recommendation on fertility preservation in borderline ovarian neoplasm: ovarian stimulation and oocyte retrieval after conservative surgery. Gynecol Obstet Invest 70:160-165. https://doi.org/10.1159/000316264

45. Rizzuto I, Behrens RF, Smith LA (2013) Risk of ovarian cancer in women treated with ovarian stimulating drugs for infertility. Cochrane Database Syst Rev 8:CD008215. https://doi. org/10.1002/14651858.CD008215.pub2

46. Wallace WH, Thomson AB, Saran F, Kelsey TW (2005) Predicting age of ovarian failure after radiation to a field that includes the ovaries. Int J Radiat Oncol Biol Phys 62:738-744

47. Teh WT, Stern C, Chander S, Hickey M (2014) The impact of uterine radiation on subsequent fertility and pregnancy outcomes. Biomed Res Int 2014:482968. https://doi. org/10.1155/2014/482968

48. Yamamoto R, Okamoto K, Yukiharu T, Kaneuchi M, Negishi H, Sakuragi N, Fujimoto S (2001) A study of risk factors for ovarian metastases in stage Ib-IIIb cervical carcinoma and analysis of ovarian function after a transposition. Gynecol Oncol $82: 312-316$

49. Ronnett BM, Yemelyanova AV, Vang R, Gilks CB, Miller D, Gravitt PE, Kurman RJ (2008) Endocervical adenocarcinomas with ovarian metastases: analysis of 29 cases with emphasis on minimally invasive cervical tumors and the ability of the metastases to simulate primary ovarian neoplasms. Am J Surg Pathol 32:1835-1853

50. Bastings L, Beerendonk CC, Westphal JR, Massuger LF, Kaal SE, van Leeuwen FE, Braat DD, Peek R (2013) Autotransplantation of cryopreserved ovarian tissue in cancer survivors and the risk of reintroducing malignancy: a systematic review. Hum Reprod Update 19:483-506

51. Kyrgiou M, Mitra A, Arbyn M, Stasinou SM, Martin-Hirsch P, Bennett P, Paraskevaidis E (2014) Fertility and early pregnancy outcomes after treatment for cervical intraepithelial neoplasia: systematic review and meta-analysis. BMJ 349:g6192

52. Wright JD, NathavithArana R, Lewin SN, Sun X, Deutsch I, Burke WM, Herzog TJ (2010) Fertility-conserving surgery for young women with stage IA1 cervical cancer: safety and access. Obstet Gynecol 115:585-590. https://doi.org/10.1097/ AOG.0b013e3181d06b68
53. Spoozak L, Lewin SN, Burke WM, Deutsch I, Sun X, Herzog TJ, Wright JD (2012) Microinvasive adenocarcinoma of the cervix. Am J Obstet Gynecol 206:80.e1-80.e6. https://doi.org/10.1016/j. ajog.2011.07.029

54. D'argent D, Martin X, Sacchetoni A, Mathevet P (2000) Laparoscopic vaginal radical trachelectomy: a treatment to preserve the fertility of cervical carcinoma patients. Cancer 88:1877-1882

55. Vercellino GF, Piek JM, Schneider A, Kohler C, Mangler M, Speiser D, Chiantera V (2012) Laparoscopic lymph node dissection should be performed before fertility preserving treatment of patients with cervical cancer. Gynecol Oncol 126:325-329

56. Slama J, Cerny A, Dusek L, Fischerova D, Zikan M, Kocian R, Germanova A, Cibula D (2016) Results of less radical fertilitysparing procedures with omitted parametrectomy for cervical cancer: 5 years of experience. Gynecol Oncol 142:401-404. https://doi.org/10.1016/j.ygyno.2016.07.008

57. Zapardiel I, Cruz M, Diestro MD, Requena A, Garcia-Velasco JA (2016) Assisted reproductive techniques after fertility-sparing treatments in gynaecological cancers. Hum Reprod Update. https://doi.org/10.1093/humupd/dmv066

58. Lyu J, Sun T, Tan X (2014) Ovarian preservation in young patients with stage I cervical adenocarcinoma: a surveillance, epidemiology, and end results study. Int J Gynecol Cancer 24:1513-1520

59. Robova H, Halaska MJ, Pluta M, Skapa P, Matecha J, Lisy J, Rob L (2014) Oncological and pregnancy outcomes after high-dose density neoadjuvant chemotherapy and fertility-sparing surgery in cervical cancer. Gynecol Oncol 135:213-216

60. Bentivegna E, Maulard A, Pautier P, Chargari C, Gouy S, Morice $P$ (2016) Fertility results and pregnancy outcomes after conservative treatment of cervical cancer: a systematic review of the literature. Fertil Steril 106(1195-1211):e5. https://doi.org/10.1016/j. fertnstert.2016.06.032

61. Willows K, Lennox G, Covens A (2016) Fertility-sparing management in cervical cancer: balancing oncologic outcomes with reproductive success. Gynecol Oncol Res Pract 3:9 (eCollection 2016)

62. Okugawa K, Kobayashi H, Sonoda K, Kaneki E, Kawano Y, Hidaka N, Egashira K, Fujita Y, Yahata H, Kato K (2017) Oncologic and obstetric outcomes and complications during pregnancy after fertility-sparing abdominal trachelectomy for cervical cancer: a retrospective review. Int J Clin Oncol 22:340-346. https://doi.org/10.1007/s10147-016-1059-9

63. Feng Y, Cao T, Wang Y, Huang H, Xie Y, Liu J (2016) Neoadjuvant chemotherapy followed by conization to spare fertility in cases of locally advanced cervical cancer: a case report and review of the literature. Mol Clin Oncol 5:411-416

64. Mossa B, Schimberni M, Di Benedetto L, Mossa S (2015) Ovarian transposition in young women and fertility sparing. Eur Rev Med Pharmacol Sci 19:3418-3425

65. Kinjyo Y, Kudaka W, Ooyama T, Inamine M, Nagai Y, Aoki Y (2015) Ovarian preservation in young women with endometrial cancer of endometrioid histology. Acta Obstet Gynecol Scand 94:430-434. https://doi.org/10.1111/aogs.12588

66. Dogan A, Schultheis B, Rezniczek GA, Hilal Z, Cetin C, Häusler G, Tempfer CB (2017) Synchronous endometrial and ovarian cancer in young women: case report and review of the literature. Anticancer Res 37:969-978

67. Shan BE, Ren YL, Sun JM, Tu XY, Jiang ZX, Ju XZ, Zang RY, Wang HY (2013) A prospective study of fertility-sparing treatment with megestrol acetate following hysteroscopic curettage for well-differentiated endometrioid carcinoma and atypical hyperplasia in young women. Arch Gynecol Obstet 288:1115-1123

68. Kim MK, Seong SJ, Kim YS, Song T, Kim ML, Yoon BS, Jun HS, Lee YH (2013) Combined medroxyprogesterone acetate/ 
levonorgestrel-intrauterine system treatment in young women with early-stage endometrial cancer. Am J Obstet Gynecol 209:358.e1-358.e4

69. Kalogera E, Dowdy SC, Bakkum-Gamez JN (2014) Preserving fertility in young patients with endometrial cancer: current perspectives. Int J Womens Health 6:691-701

70. Pronin SM, Novikova OV, Andreeva JY, Novikova EG (2015) Fertility-sparing treatment of early endometrial cancer and complex atypical hyperplasia in young women of childbearing potential. Int J Gynecol Cancer 25:1010-1014

71. Poilblanc M, Samouelian V, Querleu D (2012) Ovarian preservation during treatment of early stage endometrial cancer. Bull Cancer 99:61-68

72. Zivanovic O, Carter J, Kauff ND, Barakat RR (2009) A review of the challenges faced in the conservative treatment of young women with endometrial carcinoma and risk of ovarian cancer. Gynecol Oncol 115:504-509

73. Lee TS, Lee JY, Kim JW, Oh S, Seong SJ, Lee JM, Kim TJ, Cho CH, Kim SM, Park CY (2013) Outcomes of ovarian preservation in a cohort of premenopausal women with early-stage endometrial cancer: a Korean Gynecologic Oncology Group study. Gynecol Oncol 131:289-293

74. Wright JD, Jorge S, Tergas AI, Hou JY, Burke WM, Huang Y, Hu JC, Ananth CV, Neugut AI, Hershman DL (2016) Utilization and outcomes of ovarian conservation in premenopausal women with endometrial cancer. Obstet Gynecol 127:101-108. https:// doi.org/10.1097/AOG.0000000000001181

75. Park JY, Nam JH (2015) Progestins in the fertility-sparing treatment and retreatment of patients with primary and recurrent endometrial cancer. Oncologist 20:270-278

76. Inoue $\mathrm{O}$, Hamatani $\mathrm{T}$, Susumu $\mathrm{N}$, Yamagami W, Ogawa S, Takemoto T, Hirasawa A, Banno K, Kuji N, Tanaka M, Aoki D (2016) Factors affecting pregnancy outcomes in young women treated with fertility-preserving therapy for well-differentiated endometrial cancer or atypical endometrial hyperplasia. Reprod Biol Endocrinol 14:2. https://doi.org/10.1186/s12958-015-0136-7

77. Ioannidis JP, Katsifis GE, Tzioufas AG, Moutsopoulos HM (2002) Predictors of sustained amenorrhea from pulsed intravenous cyclophosphamide in premenopausal women with systemic lupus erythematosus. J Rheumatol 29:2129-2135

78. Park MC, Park YB, Jung SY, Sbai A, Costedoat N, Wechsler B, Piette JC (2004) Risk of ovarian failure and pregnancy outcome in patients with lupus nephritis treated with intravenous cyclophosphamide pulse therapy. Lupus 13:569-574

79. Henes M, Froeschlin J, Taran FA, Brucker S, Rall KK, Xenitidis T, Igney-Oertel A, Lawrenz B, Henes J (2015) Ovarian reserve alterations in premenopausal women with chronic inflammatory rheumatic diseases: impact of rheumatoid arthritis, Behcet's disease and spondyloarthritis on anti-Mullerian hormone levels. Rheumatology (Oxford) 54:1709-1712

80. Lawrenz B, Henes J, Henes M, Neunhoeffer E, Schmalzing M, Fehm T, Kotter I (2011) Impact of systemic lupus erythematosus on ovarian reserve in premenopausal women: evaluation by using anti-Muellerian hormone. Lupus 20:1193-1197

81. Mont'Alverne AR, Pereira RM, Yamakami L, Viana VS, Baracat EC, Bonfa E, Silva CA (2014) Reduced ovarian reserve in patients with takayasu arteriitis. J Rheumatol 41:2055-2059

82. Andreoli L, Bertsias GK, Agmon-Levin N, Brown S, Cervera R, Costedoat-Chalumeau N, Doria A, Fischer-Betz R, Forger F, Moraes-Fontes MF, Khamashta M, King J, Lojacono A, Marchiori F, Meroni PL, Mosca M, Motta M, Ostensen M, Pamfil C, Raio L, Schneider M, Svenungsson E, Tektonidou M, Yavuz S, Boumpas D, Tincani A (2017) EULAR recommendations for women's health and the management of family planning, assisted reproduction, pregnancy and menopause in patients with systemic lupus erythematosus and/or antiphospholipid syndrome. Ann Rheum Dis 76:476-485. https://doi.org/10.1136/annrheumdis-2016-209770

83. Mok CC, Wong RW, Lau CS (1999) Ovarian failure and flares of systemic lupus erythematosus. Arthritis Rheum 42:1274-1280

84. von Wolff M, Stute P (2017) Judging the fertility protective effect of GnRH agonists in chemotherapy-it is a matter of perspective. Front Endocrinol (Lausanne) 10(8):69. https://doi. org/10.3389/fendo.2017.00069

85. Badawy A, Elnashar A, El-Ashry M, Shahat M (2009) Gonadotropin-releasing hormone agonists for prevention of chemotherapy-induced ovarian damage: prospective randomized study. Fertil Steril 91:694-697

86. Somers EC, Marder W, Christman GM, Ognenovski V, McCune WJ (2005) Use of a gonadotropin-releasing hormone analog for protection against premature ovarian failure during cyclophosphamide therapy in women with severe lupus. Arthritis Rheum 52:2761-2767

87. Blumenfeld Z, Shapiro D, Shteinberg M, Avivi I, Nahir M (2009) Preservation of fertility and ovarian function and minimizing gonadotoxicity in young women with systemic lupus erythematosus treated by chemotherapy. Lupus 9:401-405

88. Marder W, McCune WJ, Wang L, Wing JJ, Fisseha S, McConnell DS, Christman GM, Somers EC (2012) Adjunctive $\mathrm{GnRH}$ - a treatment attenuates depletion of ovarian reserve associated with cyclophosphamide therapy in premenopausal SLE patients. Gynecol Endocrinol 28:624-627

89. Guballa N, Sammaritano L, Schwartzman S, Buyon J, Lockshin MD (2000) Ovulation induction and in vitro fertilization in systemic lupus erythematosus and antiphospholipid syndrome. Arthritis Rheum 43:550-556

90. Reynaud Q, Lega JC, Mismetti P, Chapelle C, Wahl D, Cathebras P, Laporte S (2014) Risk of venous and arterial thrombosis according to type of antiphospholipid antibodies in adults without systemic lupus erythematosus: a systematic review and meta-analysis. Autoimmun Rev 13:595-608

91. Raciborska A, Bilska K, Filipp E, Drabko K, Rogowska E, Chaber R, Pogorzała M, Połczyńska K, Adrianowska N, Rodriguez-Galindo C, Maciejewski T (2015) Ovarian function in female survivors after multimodal Ewing sarcoma therapy. Pediatr Blood Cancer 62:341-345. https://doi.org/10.1002/ pbc. 25304

92. Greve T, Wielenga VT, Grauslund M, Sorensen N, Christiansen DB, Rosendahl M, Yding Andersen C (2013) Ovarian tissue cryopreserved for fertility preservation from patients with Ewing or other sarcomas appear to have no tumour cell contamination. Eur J Cancer 49:1932-1938

93. Abir R, Feinmesser M, Yaniv I, Fisch B, Cohen IJ, Ben-Haroush A, Meirow D, Felz C, Avigad S (2010) Occasional involvement of the ovary in Ewing sarcoma. Hum Reprod 25:1708-1712

94. Sorensen SD, Greve T, Wielenga VT, Wallace WH, Andersen CY (2014) Safety considerations for transplanting cryopreserved ovarian tissue to restore fertility in female patients who have recovered from Ewing's sarcoma. Future Oncol 10:277-283

95. Dolmans MM, Iwahara Y, Donnez J, Soares M, Vaerman JL, Amorim CA, Poirel H (2016) Evaluation of minimal disseminated disease in cryopreserved ovarian tissue from bone and soft tissue sarcoma patients. Hum Reprod 31:2292-2302. https://doi. org/10.1093/humrep/dew193

96. Irtan S, Orbach D, Helfre S, Sarnacki S (2013) Ovarian transposition in prepubescent and adolescent girls with cancer. Lancet Oncol 14:601-608

97. Longhi A, Pignotti E, Versari M, Asta S, Bacci G (2003) Effect of oral contraceptive on ovarian function in young females undergoing neoadjuvant chemotherapy treatment for osteosarcoma. Oncol Rep 10:151-155 
98. Strong M, Peche W, Scaife C (2007) Incidence of fertility counseling of women of child-bearing age before treatment for colorectal cancer. Am J Surg 194:765-767 (discussion 767-768)

99. O’Neill MT, Ni Dhonnchu T, Brannigan AE (2011) Topic update: effects of colorectal cancer treatments on female fertility and potential methods for fertility preservation. Dis Colon Rectum 54:363-369

100. Wan J, Gai Y, Li G, Tao Z, Zhang Z (2015) Incidence of chemotherapy- and chemoradiotherapy-induced amenorrhea in premenopausal women with stage II/III colorectal cancer. Clin Colorectal Cancer 14:31-34. https://doi.org/10.1016/j.clcc.2014.09.012

101. Elis A, Tevet A, Yerushalmi R, Blickstein D, Bairy O, Dann EJ, Blumenfeld Z, Abraham A, Manor Y, Shpilberg O, Lishner M (2006) Fertility status among women treated for aggressive nonHodgkin's lymphoma. Leuk Lymphoma 47:623-627

102. Carter A, Robison LL, Francisco L, Smith D, Grant M, Baker KS, Gurney JG, McGlave PB, Weisdorf DJ, Forman SJ, Bhatia S (2006) Prevalence of conception and pregnancy outcomes after hematopoietic cell transplantation: report from the Bone Marrow Transplant Survivor Study. Bone Marrow Transpl 37:1023-1029

103. Briseno-Hernandez AA, Quezada-Lopez DR, Castaneda-Chavez A, Dassaejv Macias-Amezcua M, Pintor-Belmontes JC (2014) Bilateral ovarian Burkitt's lymphoma. A case presentation. Cir Cir 82:212-218

104. Jadoul P, Kim SS, ISFP Practice Committee (2012) Fertility considerations in young women with hematological malignancies. J Assist Reprod Genet 29:479-487. https://doi.org/10.1007/ s10815-012-9792-0

105. Alvarnas JC, Brown PA, Aoun P, Ballen KK, Barta SK, Borate U, Boyer MW, Burke PW, Cassaday R, Castro JE, Coccia PF, Coutre SE, Damon LE, DeAngelo DJ, Douer D, Frankfurt O, Greer JP, Johnson RA, Kantarjian HM, Klisovic RB, Kupfer G, Litzow M, Liu A, Rao AV, Shah B, Uy GL, Wang ES, Zelenetz AD, Gregory K, Smith C (2015) Acute lymphoblastic leukemia, version 2.2015. J Natl Compr Canc Netw 10:1240-1279

106. Dolmans MM, Marinescu C, Saussoy P, Van Langendonckt A, Amorim C, Donnez J (2010) Reimplantation of cryopreserved ovarian tissue from patients with acute lymphoblastic leukemia is potentially unsafe. Blood 116:2908-2914

107. Practice Committee ISFP, Kim SS, Donnez J, Barri P, Pellicer A, Patrizio P, Rosenwaks Z, Nagy P, Falcone T, Andersen C, Hovatta O, Wallace H, Meirow D, Gook D, Kim SH, Tzeng CR, Suzuki S, Ishizuka B, Dolmans MM (2012) Recommendations for fertility preservation in patients with lymphoma, leukemia, and breast cancer. J Assist Reprod Genet 29:465-468. https://doi. org/10.1007/s10815-012-9786-y

108. Salooja N, Szydlo RM, Socie G, Rio B, Chatterjee R, Ljungman P, Van Lint MT, Powles R, Jackson G, Hinterberger-Fischer M, Kolb HJ, Apperley JF, Late Effects Working Party of the European Group for Blood and Marrow Transplantation (2001) Pregnancy outcomes after peripheral blood or bone marrow transplantation: a retrospective survey. Lancet 358:271-276

109. Hurmuz P, Sebag-Montefiore D, Byrne P, Cooper R (2012) Successful spontaneous pregnancy after pelvic chemoradiotherapy for anal cancer. Clin Oncol (R Coll Radiol) 24:455-457

110. De Menezes E, Tuck SM (2007) Pelvic radiotherapy damage to the endometrium causing morbid adherence of placenta. A new risk factor? J Obstet Gynaecol 27:526-527

111. Bath LE, Tydeman G, Critchley HO, Anderson RA, Baird DT, Wallace WH (2004) Spontaneous conception in a young woman who had ovarian cortical tissue cryopreserved before chemotherapy and radiotherapy for a Ewing's sarcoma of the pelvis: case report. Hum Reprod 19:2569-2572

112. Wallace WH, Thomson AB, Kelsey TW (2003) The radiosensitivity of the human oocyte. Hum Reprod 18:117-121

113. Muñoz M, Santaballa A, Seguí MA, Beato C, de la Cruz S, Espinosa J, Fonseca PJ, Perez J, Quintanar T, Blasco A (2016) SEOM Clinical Guideline of fertility preservation and reproduction in cancer patients. Clin Transl Oncol 18:1229-1236

114. Lee SJ, Schover LR, Partridge AH, Patrizio P, Wallace WH, Hagerty K, Beck LN, Brennan LV, Oktay K, American Society of Clinical Oncology (2006) American Society of Clinical Oncology recommendations on fertility preservation in cancer patients. J Clin Oncol 24:2917-2931 